Revue Française de Civilisation Britannique

XXII-1 | 2017

The Book of Common Prayer : Studies in Religious

Transfer

\title{
Promoting Anglican Liturgical Spirituality: Thomas Comber's Companions to the Book of Common Prayer
}

Promouvoir la spiritualité liturgique anglicane: Les commentaires du Book of Common Prayer par Thomas Comber

\section{Rémy Bethmont}

\section{(2) OpenEdition}

\section{Journals}

Electronic version

URL: http://journals.openedition.org/rfcb/1226

DOI: $10.4000 /$ rfcb.1226

ISSN: 2429-4373

\section{Publisher}

CRECIB - Centre de recherche et d'études en civilisation britannique

\section{Electronic reference}

Rémy Bethmont, «Promoting Anglican Liturgical Spirituality: Thomas Comber's Companions to the Book of Common Prayer », Revue Française de Civilisation Britannique [Online], XXII-1 | 2017, Online since 02 May 2017, connection on 19 April 2019. URL : http://journals.openedition.org/rfcb/1226 ; DOI : $10.4000 /$ rfcb. 1226

This text was automatically generated on 19 April 2019.

\section{c)}

Revue française de civilisation britannique est mis à disposition selon les termes de la licence Creative Commons Attribution - Pas d'Utilisation Commerciale - Pas de Modification 4.0 International. 


\title{
Promoting Anglican Liturgical Spirituality: Thomas Comber's Companions to the Book of Common Prayer
}

\author{
Promouvoir la spiritualité liturgique anglicane: Les commentaires du Book of \\ Common Prayer par Thomas Comber
}

Rémy Bethmont

1 The great sense of liturgical continuity between the different versions of the Prayer Book, as well as with some aspects of medieval liturgy, provided Late Stuart Anglicans with a liturgical patrimony which to them was probably as hallowed by time and continuous use as the Sarum rite must have felt to late medieval Christians.

The Prayer Book provided the basis of a liturgical spirituality that was unique to the Church of England among Protestant Churches. After the episodes of the civil wars and Commonwealth, during which the Book of Common Prayer was suppressed, many supporters of Cranmer's liturgies felt it was their duty to reintroduce them to the people by producing commentaries of the Prayer Book. While many strove first and foremost to present the liturgy as orthodox and rightly reformed, one commentator, Thomas Comber, sowed the seeds of a more devotional approach: his monumental commentary of the Prayer Book sought to encourage the development of a liturgical spirituality in both clergy and people by uniting the private and public use of the Book of Common Prayer.

The continuous controversies about the Book of Common Prayer since the Elizabethan era gave rise to several defences of Cranmer's liturgies. Their orthodoxy and conformity with the most venerable patristic tradition were vindicated in Richard Hooker's Book V of the Laws of Ecclesiastical Polity (1597), and their scripturality was underlined in John Boys's survey of the biblical passages of which the text of the Prayer Book is largely composed. ${ }^{1}$ After the years of the civil wars and Commonwealth, in which those who were attached to the liturgy had had to take risks to continue to use it, praying according to the Prayer 
Book came to be seen at the Restoration as a more defining mark of belonging to the established Church than it had ever been. It is therefore not surprising that the Restoration Church should have produced several commentaries on the Book of Common Prayer, starting what became a veritable industry within Anglicanism. Most of these commentaries were in continuity with the apologetic and analytic mode in which Hooker had written: one now defended the liturgy against the criticisms of the Dissenters and one wished to commend it to those who had grown up without it in the 1640s and 1650s. Thomas Comber's Companions to the Book of Common Prayer do all this but they also stand out by the scope and importance of their devotional content. They promote the use of the Book of Common Prayer, not just as the biblical, orthodox, public liturgy of the Church, but more profoundly perhaps as the outward form of the prayer of the heart, which can best unite private and public devotion. In that respect, no matter how uninspiring Comber seems to have been to modern scholarship, ${ }^{2}$ his commentary of the Prayer Book helped towards the diffusion of a liturgical form of spirituality that became defining of "Anglicanism" and which sought to present itself as a profitable resource for all Christians, not only within but also beyond Anglicanism.

\section{Making the liturgy understood and loved}

Thomas Comber (1644-1699) was ordained to the priesthood in 1664. His whole clerical career unfolded in Yorkshire. He was first curate and then incumbent of the parish of Stonegrave, while acting as chaplain to the Thorntons, a local gentry family into which he married in 1668. In 1677 he became a prebendary of York, and precentor in 1683. His career climaxed in the wake of the Glorious Revolution, which he supported. He replaced Denis Granville, the Non-juring Dean of Durham, in 1691 and was also made chaplain-inordinary to William and Mary in 1692.

5 His commentary on the Book of Common Prayer, which he published, volume after volume, between 1672 and 1698, is what he is chiefly remembered for. The last volumes, on the state services ${ }^{3}$ and the ordinal, ${ }^{4}$ published respectively in 1696 and 1698, can be seen as late additions to the four main volumes that made him famous: A Companion to the Temple on the daily office (16725), A Companion to the Altar on Holy Communion, Baptism and Confirmation (1675), the second part of A Companion to the Temple on the litany and the occasional prayers and thanksgivings (1679) and The Occasional Offices of Matrimony, Visitation of the Sick, Burial of the Dead, Churching of Women and the Commination (1679). These four parts were subsequently published bound together in one volume entitled $A$ Companion to the Temple in 1684. An abridged edition of this one-volume version came out one year later. ${ }^{6}$ It is these four parts of Comber's commentary on the Book of Common Prayer and particularly the more popular volumes on the daily office, the litany and Holy Communion that this paper focuses on.

When Comber set out to write his Companion to the Temple, his aim was to both vindicate the excellence of the Restoration liturgy and to encourage the English to attend daily prayer in church. In his mind, both the attacks on the Prayer Book by Dissenters and low attendance at the daily office in parish churches were due to the fact that the liturgy was not sufficiently understood. He echoed a widespread concern at that period that Charles II himself had addressed on his return to England in his "Gracious Letter Touching Catechising' that attributed "contempt among the people" for the "prayers of the church" to the fact that "they were not understood." Clergymen were asked to instruct 
the people about the meaning of the liturgy and a number of publications proposing to meet that demand had preceded Comber's Companion to the Temple, in particular Thomas Elborow's Exposition of the Book of Common Prayer (1663), followed by complementing volumes in the 1670's. Even before the Restoration, concern for making the liturgy plain so that it might be loved was visible in Anthony Sparrow's Rationale upon the Book of Common Prayer, first published in 1655 and reedited in 1672. Comber's commentaries were hardly an isolated publishing phenomenon. However, they stand out by the thoroughness with which he comments every single sentence of every Prayer Book service and also by the fact that his goal is much more explicitly devotional than any of the other commentaries.

\section{The devotional dimension and method of Comber's Companions}

7 Comber does more than analyse the structure and meaning of the liturgy or generally defend the restored Prayer Book by showing, as Sparrow does in his Rationale, that the liturgy is thoroughly reasonable, grounded on Scripture and in line with the prayers of the patristic church. ${ }^{8}$ Ultimately the analytic and apologetic dimension of Comber's commentary is merely a tool serving his overriding preoccupation: increasing lively, heart-felt devotion in the Church of England, which alone will commend daily liturgical prayer to those who either oppose or have become indifferent to it.

8 Three kinds of people are on Comber's mind, as he explains in the preface to A Companion to the Temple: the "mistaken dissenters who hereby may be convinced ... that we can pray by this form with as much zeal and more knowledge, with as much spirit and more truth than by any other kind of prayer;" the "ignorant, who may be instructed thereby to pray with understanding," and finally, the "devout servants of God, and obedient sons of the Church", who already attend daily prayers in church and are to be encouraged to deepen their devotions. All three categories are to be shown ways to "elevate the affections," as Combers says in the section about the ignorant, so that the "daily offices may be full of life and pleasure; and every day court us with new delights."

In order to do so, Comber proposes to methodically go through the services he comments. Each section of the liturgy is presented in a threefold manner: the structure of the particular prayer or exhortation is graphically shown, often in a way that enables the reader to have an overview of the whole prayer or exhortation (so that many sections of Comber's commentary herald the kind of annotated Book of Common Prayer that William Nicholls published in $1709^{10}$ ). Then a "practical discourse" on the text analyses its meaning, defends its orthodoxy if necessary and accounts for its place in the overall structure of the service of which it is part. Sometimes (especially in the commentary on Holy Communion), this discourse may also contain meditative prayers of Comber's own making. Finally, a paraphrase of the prayer is given which weaves together the words from the Book of Common Prayer and Comber's own phrases, referring the reader back to the main ideas developed in the practical discourse. Throughout, the actual words taken from the Prayer Book are typographically set apart in gothic, whereas Comber's own words are in roman type. The aim of that methodical exposition is clear: invite readers to deepen their understanding of the liturgy in order to enliven their devotions. Understanding with one's mind must lead to praying with one's heart: 
when once we have thoroughly pondered them [i.e. the words of the liturgy], and made our souls fully acquainted with these pertinent and comprehensive expressions of our constant necessities, we shall find our hearts actuated with holy enlargements, and powerfully attracted into the prosecution of the requests made by our lips; and our minds would have no other employment in these duties, but to annex the sense to the words, and its most vigorous affections to that sense, which is true devotion. ${ }^{11}$

Ultimately, it is a devotional method that Comber tries to convey: his own comments, paraphrases and meditations are not presented as the be-all and end-all of liturgical devotional exercises, but rather as crutches for beginners and, for those who are more spiritually advanced, as showing the way towards "making pathetical and pious enlargements, more and better than are to be found here." ${ }^{12}$ By learning and applying the commentary's method, Comber hopes, they will eventually be able to use the Prayer Book creatively and find their own way towards the prayer of the heart.

\section{Promoting the use of the Prayer Book in private devotions}

11 The thoroughness with which Comber deals with the content of the Book of Common Prayer means that it takes time to read through his commentary and paraphrase of just one prayer. For example, the practical discourse on the daily confession in Morning Prayer is 39 pages long in the 1676 edition, followed by four pages of paraphrase. Clearly the book was meant to be read and studied at home, as part of a devout Christian's private devotions: "if we desire to pray acceptably, we must study our petitions before we present them; which not only enlivens our devotions in the act of it, but makes our prayers become the rule of our lives. ${ }^{{ }^{13}}$ It is remarkable that the complete title of $A$ Companion to the Temple in its first edition was A Companion to the Temple and Closet, or a help to public and private devotion. This title was changed in subsequent editions to the more general phrasing of A Companion to the Temple, or a Help to Devotion in the Daily Use of Common Prayer. But the original title is an accurate description of Comber's aim: making the liturgy the rule of believers' lives by encouraging them to experience close correspondence between their private devotions in the closet and public prayers in church.

It is not simply an intellectual study of the liturgy in private that reading Comber's Companions effects. The very structure of each section, in which analytical, learned comments in the practical discourse are followed by a devotional paraphrase of the words of the liturgy, would lead the devout reader from study to meditative prayer even in the closet. A parallel may be made with the private, prayerful study of the Bible, which was so dear to English Protestants and of which Joseph Hall's biblical Contemplations are an example. ${ }^{14}$ The same pattern from study to prayer can be observed; the Prayer Book has joined the Bible as study/prayer material. Comber's idea is to unite private and public devotions by promoting the use of the authorised liturgy for both.

The private use of Common Prayer was hardly new. In the $16^{\text {th }}$ century, most of the content of the Edwardian and Elizabethan primers of 1553 and 1560 or Books of Private Prayer, was a selection of services and prayers from the Book of Common Prayer, encouraging devout, literate Christians to say Morning Prayer, Evening Prayer, the Litany and chosen collects in private as well as in their parish church. And closer to Comber's 
time, the years of the civil wars and Commonwealth, when the Prayer Book was banned, had occasioned the increasing private use of the liturgy by those who refused to abandon it. Many people used the forbidden liturgy at home as a book of family and private prayer. ${ }^{15}$ In 1672, the same year as the publication of Comber's first part of the Companion to the Temple, Anthony Sparrow commended the private use of Morning and Evening Prayer when it was not possible to go to church in the reedition of his Rationale upon the Book of Common Prayer. ${ }^{16}$ Comber himself repeatedly seems to hint at what must have been a sufficiently established and widespread practice not to need any explanation. In his commentary of the Collect for Pardon in part II of A Companion to the Temple, for example, he declares that "some devout Christians, who use the Common-Prayer in private, as their daily Service of God, do use this Form instead of the Absolution, which no ordinary person may pronounce, nor can any properly use it to himself, but they may petition for forgiveness in this form." ${ }^{17}$ This comment hints at the fact that the Book of Common Prayer had started to be seen by some as a resource for private prayer which could be used creatively, more so in fact than it had been in the Edwardian and Elizabethan primers one century before. ${ }^{18}$

\section{The Book of Common Prayer as a school of devotion uniting the personal and the communal}

Comber was not therefore being particularly original in relating the Book of Common Prayer to private devotion. The novelty of Thomas Comber's commentary lies in its invitation to use the Book of Common Prayer as a school of devotion. When the liturgy is rightly understood and approached with the right method (which the Companion to the Temple provides), the words of the prayers become prompters which bring us, says Comber, to "enlarge our souls in holy and fervent wishes, desires and meditations, which is the prayer of the inward man, the life and soul of his duty." ${ }^{19}$ When by frequent reading of the commentary, the believer has learnt to discern in the particular prayers, phrases and words of the liturgy signals that should trigger certain movements of the soul, he or she is in the right disposition to attain true devotion.

This is particularly striking in the use Comber suggests the reader should make of $A$ Companion to the Altar. While it is possible to say morning and evening prayer privately, a sacramental service like Holy Communion can only be celebrated communally with a minister officiating. Spiritual preparation at home for receiving the sacrament was something that had been encouraged ever since the Book of Common Prayer was first authorized and various books of devotion, such as the widely read The Whole Duty of Man (1658), gave assistance to the Christian preparing for Holy Communion, in particular by suggesting how one should introspectively review one's sins in order to approach the sacrament in a penitent way and by providing private prayers of thanksgiving to be said after receiving communion. Comber takes a slightly different approach. He does offer many meditative prayers of his own composition that are quite distinct from the liturgical text. But whenever possible, he uses the liturgical prayers as the basis for private preparation for communion. It is particularly striking in the long section to help examine one's conscience, which is presented liturgically, unlike what one finds in The Whole Duty of Man, for example. The commentary and paraphrase of the collect for purity serves as a devotional introduction for an examination of conscience based on the recitation of the Ten Commandments, with each section ending by "Lord have mercy 
upon me and incline my heart to keep this law", which is the congregational response adapted for private use ("us" and "our" becoming "me" and "my") to each of the Ten Commandments. The beginning of the "practical discourse of the Ten Commandments" serves as an instruction manual: for every offense suggested by the commandments, says Comber:

Ask then your own heart seriously at every one, Have I not been such an one? Done this evil? Neglected this duty? And when your conscience answers, Yes; then you must most passionately cry out, Lord have mercy upon me, and forgive me this or that sin. ... But now that you are freshly minded of your duty, and reproved for your former neglect, it will be expected you shall be more afraid to transgress hereafter, and therefore desiring never more to offend, say, Lord incline my heart to keep this Law. $^{20}$

Moreover, at the end of the practical discourse Comber suggests that those who feel so moved can also use the confession from the order for Holy Communion as a private way to ask for God's forgiveness when they have been through their self-examination. ${ }^{21}$

Whenever possible, Comber's commentary turns the liturgy into a resource for private devotion to enable the devout Christian to better reinvest his private prayers into the public service of the Church. And when he inserts prayers of his own composition, Comber often does it in a way which develops particular sections of a liturgical text, emphasizing the dependence of his meditations on the liturgy and referring the reader back to it. For example, the post-communion prayers are commented in practical discourses which, for each liturgical sentence, conclude with a meditation of Comber's own making, to be used in the closet. As Comber explains in the introduction,

We have indeed many admirable books for our help in this sacrament; but they being generally designed for the closet, the affections which were elevated in private, are apt to grow loose and unactive when the public service doth begin. Whereas this discourse, following the order appointed for the celebration in the church, doth entertain the devout communicant all the way, with most pertinent meditations; most of which, by frequent reading them in private, may be made so familiar, that the hearing that part of the office will bring them to our minds in their proper seasons. ${ }^{22}$

The aim is to make the words of public prayer the outward form of true, inward devotion in the closet so that they might have that same inward quality in church. Comber even gives a table at the end of the introduction, directing the reader to various sections of the commentary according to the kind of devotions he wishes to engage in, from selfexamination before the service to thanksgiving after the sacrament. Thanks to the commentary, the Book of Common Prayer truly becomes the key resource for a spiritual life that unites the personal and communal dimensions of the Christian faith.

Comber's dream (like Cranmer's) was one of a nation daily attending public prayer in church and in his mind the devotional use of the Book of Common Prayer in private should serve more frequent and meaningful attendance at public services. It is this vision which is behind his commentary, even though he probably had little illusion as to its actually coming true. His insistence on the particularly low number of people necessary to make a Christian congregation compared to the Jewish minyan is telling:

The Jewish masters indeed teach that ten is the least number to make an assembly fit for the divine presence. But our gracious Lord descends lower, even unto two or three, that none might be discouraged by the negligence of their brethren. ... If you find but few of your brethren at church, yet you shall find him whom your soul seeks there. ${ }^{23}$ 

reason for this low attendance. While the dream of a whole nation attending daily public prayer may not have come any truer in Cranmer's time than in Comber's, the tendency to a certain privatized use of the Prayer Book, starting in the years of the civil wars and Commonwealth, and the association, promoted by commentaries like Comber's, between the outward public form of prayer and the private prayer of the heart may have eventually brought some devout Anglicans, whose private devotions had become increasingly based on the Prayer Book, to find it more inspiring to say the daily office in their homes and reserve church attendance for Sundays. In particular, they may well have done so when their parish priest "sa[id] the liturgy without affection," as Comber complains was too often the case, leading to "the rude and hasty repeating" of the common prayer. ${ }^{24}$ Interestingly Comber mentions private prayer as an excuse - which he considers as a hypocritical mask for irreligion - given by the laity for not attending the daily office in church. ${ }^{25}$ Perhaps it was not always hypocrisy.

\section{A liturgical spirituality that reflects a mixed heritage}

Recent scholarship on the Restoration Church has underlined the sense of unity among Episcopalians but also some degree of diversity in the relatively peaceful coexistence of former Laudians, Prayer Book Protestants and even Presbyterians who had been reconciled to the restoration of episcopacy. ${ }^{26}$ Comber's Companions seem to reflect a mixed heritage of Laudianism and of the Prayer Book Protestantism which had been an important feature of the pre-civil war Church. ${ }^{27}$ The way Comber establishes the connection between the inward prayer of the heart and the outward, set form of prayer is hardly by emphasizing the role of ceremony and of the beauty of holiness as the Laudians had done, even though his use of the word altar has a distinctly Laudian ring.

Comber certainly does pay attention to the posture of one's body in prayer, but not necessarily more so than in Elizabethan conformist worship. In the preface to $A$ Companion to the Temple, he urges worshippers to:

compose their bodies into those most reverent postures which the Church hath suited to every part of duty, kneeling at the confession, absolution and prayers; standing at the Gloria Patri, hymns and creeds, and bowing at the name of Jesus; for a general uniformity in these things doth declare, that there is in us, a due sense of the divine presence, a great obedience to our governors, and a sweet harmony between our bodies and souls in the worship we pay to the Creator of both.

Although greatly valued by the Laudians, kneeling in "common supplications to Almighty God" and bowing at the name of Jesus had been canonically required since the Elizabethan Injunctions of $1559 .{ }^{28}$ And Comber is hardly obsessed with more quintessentially Laudian themes, such as the sanctity of the house of prayer. Comments on this, as one still finds in the contemporary Prayer Book commentaries written by Thomas Elborow, ${ }^{29}$ are conspicuously absent from Comber's writings. Neither does he comment on the ornaments rubric and he only minimally remarks on the priest's posture and gestures in the service, in contrast to what Anthony Sparrow does (and profusely so!) in his Rationale upon the Book of Common Prayer. ${ }^{30}$ Comber chooses to almost exclusively focus on the spoken words of the liturgy. It is these words, more than the ceremonial beauty of holiness, that should enhance the devotional experience of public prayer. As Comber writes, "the Liturgy in its true and native lustre, ... is so lovely and ravishing, 
that, like the purest beauties, it needs no supplement of art and dressing, but conquers by its own attractives." ${ }^{31}$ emphasize the things that they most loathed and Comber may have considered that the naked words of the liturgy, more than anything else, had the devotional power to draw the Dissenters back to the prayers of the established $\mathrm{Church}^{32}$ because they were sufficient to prompt the devotional movements of the soul. ${ }^{33}$ It is therefore difficult to conclude with certainty from the Companions how much Comber's personal spirituality owed to Laudianism and how much of it reflected the legacy of Prayer Book Protestantism..$^{34}$ But what the Companions do show is that Comber was promoting a type of prayer book spirituality that creatively put together Laudian elements with indifference to certain aspects of ceremonial on which the Laudians had insisted in the 1630s. This word-based liturgical devotion, relatively indifferent (though not opposed) to ceremonial beauty, testifies to the fact that the Anglican liturgical spirituality which developed in the wake of the Restoration could quite peaceably draw from different strands of conformist tradition. Unlike Sparrow or Elborow, Comber belonged to a new generation, born during the civil wars, and he was claiming in his own way the spiritual legacy of the early Stuart Church. devotion in general, such as The Whole Duty of Man, and perhaps less so than other Prayer Book commentaries such as Anthony Sparrow's Rationale upon the Book of Common Prayer. There is evidence, however, that a number of prominent people, both in the clergy and the laity, did read at least some parts of Comber's commentaries, notably Princess Anne, who used A Companion to the Altar to prepare for her first communion in $1678 .{ }^{35}$ The thoroughness of the Companions may have looked quite daunting to a lot of lay people and it is very difficult to say how much of an impact Comber had on Prayer Book devotions. It is therefore quite comprehensible that recent scholarship should have largely ignored him and focused rather on other, more obviously influential devotional authors from that period. Still, between 1672 and 1721, the commentaries on the daily office and A Companion to the Altar, both published in various formats (from folio to octavo), ran respectively through three and five editions as stand-alone volumes and through eight as part of the combined edition. And the abridged combined volume ran through four editions. The English Short Title Catalogue contains no evidence of any reprinting of Comber's Companions after 1721. By that time other liturgical commentaries which may have proved more appealing had appeared, notably the edition of the Book of Common Prayer by William Nicholls (1709).

Whatever its impact, Comber's Companions to the Book of Common Prayer, together with the other contemporary works of Prayer Book devotion, testify to a defining moment in the history of the Church of England. One was drawing on several strands of conformist tradition to make the Book of Common Prayer central in articulating the way in which the private and the public dimension of spirituality related to each other. It was this articulation, Comber thought, which had the potential to make Anglican liturgical spirituality attractive to all kinds of English Christians, including to those who had left the established Church. Later developments on the Continent suggest that this characteristic of Anglican liturgy, with its ensuing capacity to profoundly unite all church members in one prayer, also made it appealing to a number of Protestants quite outside the Anglican fold. ${ }^{36}$

Revue Française de Civilisation Britannique, XXII-1 | 2017 


\section{NOTES}

1. In many ways, Boys comments the biblical passages in the Prayer Book more than the liturgy as such. But it was certainly a very powerful way of demonstrating the scripturality of the Book of Common Prayer, about which Boys declares: "I did ever esteem as a second Bible the Book of Common Prayer in which (as I have here proved) every title is grounded upon the Scripture, every Scripture well applied, every good application agreeable to the most ancient and best reformed Liturgies in all ages." (Works [1622], Epistle dedicatory)

2. In his monumental study of English spirituality, Horton Davies pronounces Comber "deadly dull" (Worship and Theology in England, vol. II From Andrewes to Baxter and Fox, 1603-1690, 1975, combined edition [Grand Rapids: Eerdmans, 1996], 117).

3. A Discourse on the Offices for the $V^{\text {th }}$ of November, the XXXth day of January and XXIXth of May.

4. A Discourse upon the Forms and Manner of Making, Ordaining and Consecrating Bishops, Priests and Deacons.

5. The date given is that of the first edition.

6. Short Discourses upon the whole Common Prayer (1685).

7. Reproduced on the first page of Thomas Elborow's Exposition of the Book of Common Prayer (London, 1663).

8. Sparrow's book is not devoid of "devotionally illuminating" remarks, to quote C J. Stranks Anglican Devotions: Studies in the Spiritual Life of the Church of England between the Reformation and the Oxford Movement (London: SCM Press, 1961, 153), but the thrust of his book is not to help people find ways of enlivening their devotions in public prayer.

9. Preface to A Companion to the Temple.

10. However, Nicholls's Comment on the Book of Common Prayer only deals with the daily office, the litany, and the collects as well as the Sunday readings. Like Comber he offers a paraphrase of the prayers but as footnotes on the text of the Book of Common Prayer, so that the liturgy can be read directly from the commentary without any interruption by Nicholls's own words.

11. Preface to A Companion to the Temple.

12. Preface to A Companion to the Temple.

13. Epistle dedicatory of the first edition of A Companion to the Temple (1672).

14. Rémy Bethmont, L'Anglicanisme : un modèle pour le christianisme à venir? (Genève: Labor et Fides, 2010), 47-51.

15. See Judith Maltby, "Suffering and Surviving: the Civil Wars, the Commonwealth and the Formation of 'Anglicanism', 1642-60," Religion in Revolutionary England, ed. Christopher Durston and Judith Maltby (Manchester: Manchester University Press, 2006), 166-7.

16. Rationale on the Book of Common Prayer (1672), 333-5.

17. A Companion to the Temple, part II (1679), 448.

18. Strikingly the absolution, which is the only part of Morning Prayer which has to be said by a priest was retained in the primers, only switching from the third to the first person so that the actual performative words of the absolution became simply declarative of the fact that God pardons: "Almighty God, ..., which desireth not the death of a sinner, ... and hast given power and commandment to thy ministers, to declare and pronounce to thy people, being penitent, the absolution and remission of their sins, and pardonest and absolvest all them which truly repent..." A Primer or Boke of Private Praier [1560].

19. Preface to A Companion to the Temple.

20. A Companion to the Altar, 12. The page numbers given are those of the 1675 edition. 
21. A Companion to the Altar, 27.

22. A Companion to the Altar, introduction, $\$ 3$.

23. A Companion to the Temple (1676), 448.

24. Preface to A Companion to the Temple.

25. Preface to A Companion to the Temple.

26. See especially John Spurr, The Restoration Church of England, 1646-1689 (New Haven: Yale University Press, 1991) and Kenneth Fincham \& Nicholas Tyacke, Altars Restored: The Changing Face of English Religious Worship, 1547-c. 1700, (Oxford: Oxford University Press, 2007), 305-352.

27. Judith Maltby has very well shown that the defence of conformist worship and love of the Book of Common Prayer in the laity under Charles I could be - and mostly was - robustly antiLaudian. See Prayer Book and People in Elizabethan and Early Stuart England (Cambridge: Cambridge UP, 1998), especially chapters 3 and 4.

28. Injunction 52 .

29. Elborow's preface to The Reasonableness of our Christian Service (London, 1677) starts with an exhortation to demean oneself "with all the reverence imaginable" when one comes into church, "that holy place", where God's "special presence" abides.

30. For example, there is a thirteen-page long development on the ornaments rubric (A Rationale upon the Book of Common Prayer [London, 1672], 322-32 and 335-6) and four pages are devoted to defend the idea of the priest facing one way when he speaks to God and another when he addresses the congregation (35-9). These passages are an occasion for Sparrow to discuss what he sees as the sacred symbolism of the church building, something which is quite absent from Comber's discourse. Sparrow also has a lot more to say than Comber on the symbolism of the priest standing or kneeling (14 and 65 for example).

31. Preface to A Companion to the Temple.

32. Comber actually had some dissenting friends whom he tried and sometimes managed to reconcile to the established Church, as was the case in 1690 with "a learned \& moderate Presbyterian friend of mine who had lost a good liveing in 1662" (C. E. Whiting, ed., The Autobiographies and Letters of Thomas Comber, sometime Precentor of York and Dean of Durham, vol. 1, Publications of the Surtees Society, vol. CLVI [London: Andrews \& co., 1946], 23).

33. Even in what may appear as the less inspiring moments of the liturgy. The way in which Comber turns into an occasion for joy what must have felt to some as the rather tedious warning giving notice of a coming Holy Communion office is admirable: "Our Lord Jesus when he came in the flesh had St John Baptist for his herald to bid the world prepare ... thus also his Messengers do now proclaim his approach in this Sacrament, wherein he comes in the Spirit, to feast with us. ... Why should we not receive the news with the same joy that Zachaeus expressed, when he heard that Jesus purposed to be his guest?" (A Companion to the Altar, op. cit, 103)

34. Comber's autobiographical notes and letters are not more helpful than the Companions in that respect. They show him to be comfortable with the beauty of holiness but there is never any display of excitement about ceremonial. The gift of "a noble crimson velvet cloth with rich embroidery \& Gold fringe upon the Alter at York," he simply mentions as a "seasonable \& liberal gift" (C. E. Whiting, ed., op. cit., 23) and in a letter to a Dissenter he tries to reconcile him to the Church by pointing out that ceremonies are matters so indifferent and inconsequential that they cannot constitute a good reason for separation (C. E. Whiting, ed., vol. 2, op. cit., 4-5).

35. C. E. Whiting, ed., op. cit., 9. A letter by one W. R. to Comber, dated from 1676, also suggests that his commentary had had some impact in London on both clergy and laity: "divers who have hade all of them [Comber's volumes] are become constant daily prayer men and women at St Christophers, which fills morning and evening, verie much off late." (C. E. Whiting, ed., op. cit., 115) 
36. Eugène Bersier's example in the French Reformed Church is a case in point. His wish to put a prayer book in every church member's hands flowed out of his appreciation of Anglican liturgical spirituality (see Stuart Ludbrook's paper in this volume).

\section{ABSTRACTS}

Thomas Comber was the Dean of Durham from 1691 to his death in 1699 . He is chiefly remembered for his companions to the Book of Common Prayer, published between 1672 and 1699, which constitute the first complete commentary on the Prayer Book for devotional use. Whereas the desire to defend the excellence of the liturgy of the established Church against dissenting criticism is certainly not absent, the devotional dimension of Comber's commentary distinguishes it from previous commentaries, starting with Richard Hooker's in Book V of the Laws of Ecclesiastical Polity. If Comber's aim is clearly to promote the daily frequenting of morning and evening prayer in the parish church by helping the educated laity to understand and love every part of the liturgy better, his commentary is also explicitly presented as suitable for private devotions. In the 16th c. the publication of primers and books of private prayer to complement the Book of Common Prayer had seemed to confine the Prayer Book to public worship. At the end of the 17th c., Comber's commentary was an invitation to use the Prayer Book for private devotions as well. Thanks to his thorough commentaries and his prayerful paraphrase of the entire liturgy, Comber contributed to the spread of a form of liturgical spirituality, whereby every Anglican's devotional life, both personal and communal, was grounded on two books that were not to be separated: the Bible and the Book of Common Prayer.

Thomas Comber, doyen de la cathédrale de Durham de 1691 jusqu'à sa mort en 1699, a légué à la postérité son commentaire du Book of Common Prayer, publié, volume après volume, entre 1672 et 1699. Il s'agit du premier commentaire complet du livre de prières dont l'objet est d'enflammer la piété des Anglais. Si le désir de défendre l'excellence de la liturgie officielle contre les critiques des Dissidents n'est certes pas absent, l'usage méditatif et priant que Comber souhaite pour son commentaire le distingue, en effet, de ceux qui l'ont précédé, à commencer par celui de Richard Hooker dans le livre V de son of the Laws of Ecclesiastical Polity. L'objectif initial de Comber est clairement d'encourager la fréquentation quotidienne des offices du matin et du soir dans l'église paroissiale, en aidant les laïcs instruits à mieux comprendre et aimer chaque séquence de la liturgie. Mais son commentaire se présente aussi explicitement comme une aide à la méditation et à la prière personnelle. Au XVIe siècle, la publication de livres de prières privées, comme pendants du Book of Common Prayer avait semblé confiner ce dernier au culte public. A la fin du XVIIe siècle, le commentaire de Comber invite à aussi utiliser le Book of Common Prayer pour la prière et la méditation privées. Par ses analyses détaillées de la liturgie et ses paraphrases dévotionnelles, Comber a contribué à la formation d'une spiritualité liturgique dans laquelle la piété anglicane, qu'elle soit individuelle ou communautaire, s'enracine dans l'usage de deux livres inséparables: la Bible et le Book of Common Prayer. 
INDEX

Mots-clés: Réforme anglaise, Henri VIII, liturgie, Book of Common Prayer

Keywords: English Reformation, Henry VIII, liturgy, Book of Common Prayer

\section{AUTHOR}

\section{RÉMY BETHMONT}

Université Paris 8, TransCrit 